(C) 2021, The Authors. Published by Elsevier Inc. and Fass Inc. on behalf of the American Dairy Science Association ${ }^{\circledR}$. This is an open access article under the CC BY-NC-ND license (http://creativecommons.org/licenses/by-nc-nd/4.0/).

\title{
Dry period management and new high somatic cell count during the dry period in Dutch dairy herds under selective dry cow therapy
}

\author{
B. Krattley-Roodenburg, ${ }^{1 *} \odot$ L. J. Huybens, ${ }^{2} \odot$ M. Nielen, ${ }^{2} \odot$ and T. van Werven ${ }^{1,2}{ }^{\circ}$ \\ ${ }^{1}$ University Farm Animal Practice, 3481 LZ, Harmelen, the Netherlands \\ ${ }^{2}$ Faculty of Veterinary Medicine, Department of Population Health Sciences, Farm Animal Health, Utrecht University, 3584 CL, Utrecht, \\ the Netherlands
}

\begin{abstract}
The aim of this study was to describe the current management practices that could influence udder health during the dry period and to investigate the associations between management and new high SCC during the dry period. In 2008 the Netherlands started to improve transparency and decrease the use of antimicrobials in animal husbandry. Prevention of new high SCC during the dry period via antimicrobial dry cow treatment (DCT) was no longer allowed in animals with a low SCC before the dry period. An increase of new high SCC during the dry period was expected in dairy cows without antimicrobial protection, but was not observed. In 2018 an online questionnaire was conducted among 1,942 Dutch dairy farms using 12 different veterinary clinics. The questionnaire asked about the management of dry cows at the start of and during the dry period, and around calving, considerations in the use of DCT, and knowledge of the 2012 guidelines for selective DCT. A total of 690 farmers (36\%) responded to the questionnaire. Data on new high SCC during the dry period, use of antimicrobials for intramammary DCT and mastitis treatment, herd size, and milking system were available from other sources. Descriptive statistics were used to evaluate the associations between the different variables. For analysis of new high SCC on herd level, explanatory variables were analyzed using a generalized linear mixed model. Respondents indicated that the most important management factor to reduce the risk of new high SCC was reduction of milk yield before dry-off. The variables associated with a lower proportion of new high SCC on herd level during the dry period were the use of dip or spray after drying off, a higher animal-defined daily dose of intramammary antimicrobials for DCT, the use of DCT in low-SCC cows based on SCC or mastitis history, correct knowledge of the guideline, and awareness of importance of
\end{abstract}

Received June 22, 2020.

Accepted October 5, 2020.

*Corresponding author: t.vanwerven@uu.nl low infection rate and good hygiene during dry-off. The variables associated with a higher proportion of new high SCC on herd level were dry cow housing other than cubicles and a higher animal-defined daily dose for intramammary antimicrobials for mastitis. This research clearly indicates that farmers can balance limited use of antimicrobials at dry-off with management measures to maintain good udder health during the dry period.

Key words: dairy cow, dry cow management, new high SCC, selective dry cow therapy

\section{INTRODUCTION}

Blanket dry cow therapy (BDCT) with intramammary antimicrobials has long been recommended as part of udder health management on dairy farms (Neave et al., 1969; Eberhart, 1986; Dingwell et al., 2003). It is used to cure existing IMI and to prevent new high SCC during the dry period (Bradley and Green, 2004). In most countries, BDCT is common practice (Cameron et al., 2014), and this was also true in the Netherlands, where it has been advised for decades and was common: $87 \%$ of farms used BDCT in 2007 (Sampimon et al., 2009) and $61 \%$ in 2013 (Santman-Berends et al., 2016). Increasing concerns about the development of antimicrobial resistance have led to an emphasis on the reduction of antimicrobials (WHO, 2015; OIE, 2016). This led, in 2008, to Dutch livestock and veterinary associations signing an agreement to reduce the use of antimicrobials as routine preventatives (WUR, 2008). Because the use of antimicrobial dry cow therapy (DCT) in low-SCC cows is considered preventative use, it became prohibited in 2012 in the Netherlands. Instead, selective dry cow therapy (SDCT), using DCT only in cows with an IMI at drying off, became the new standard, with an estimate of $87 \%$ of farmers implementing SDCT in 2013 (Scherpenzeel et al., 2016). Dutch SDCT guidelines were published with advice on managing risk factors during the transition period and a flowchart based on SCC to select cows eligible for DCT (KNMvD, 2013). In the Nordic countries, SDCT 
had already been used for several decades (Østerås and Sølverød, 2009; Vilar et al., 2018).

Although it was assumed that applying SDCT in the Netherlands would lead to an SCC increase during the dry period and a higher rate of clinical mastitis (CM; Scherpenzeel et al., 2014), this did not happen. Without observed changes in the national bulk milk SCC dynamics over the course of the year, antimicrobial usage in dairy cattle in the Netherlands decreased noticeably (Lam et al., 2017). From 2013 to 2015, no increase was observed, either in new high SCC during the dry period (Vanhoudt et al., 2018) or in the rate of CM (Santman-Berends et al., 2016), even though $\mathrm{SDCT}$ is known to give less protection (Halasa et al., 2009). This highlighted the importance of management factors in controlling udder health during the dry period (Dingwell et al., 2003; Green et al., 2007; Bradley et al., 2015): improved management may have compensated for the increased risk of new high SCC. Additionally, several risk factors at cow level for new high SCC have been identified, including dry period length, parity, and milk yield at drying off (Dingwell et al., 2003; Rajala-Schultz et al., 2005; Green et al., 2008). However, these do not fully explain betweenherd variability (Madouasse et al., 2012; Bradley et al., 2015) and need further investigation.

The period in which the conditions around the use of DCT in the Netherlands changed is a good interval to investigate management practices and farm characteristics that are known to influence udder health. Our objectives were to describe the current management practices during the transition period that could influence udder health and to investigate the associations of the transition management and farm characteristics on new high SCC during the dry period.

\section{MATERIALS AND METHODS}

\section{Experimental Design: Questionnaire}

We developed a questionnaire to collect information on farm characteristics and transition management on dairy farms in the Netherlands. The questionnaire contained open questions, multiple-choice questions, and questions for which multiple responses could be checked. The first 7 questions were related to management before drying off cows. To get a genuine response, in these questions we emphasized answering about the last cow or groups of cows that were dried off. To determine whether the answers were representative for overall herd management, we added question 8, asking whether the previous answers were in line with their usual management practices. The next part, on transition management, contained questions on management during the dry period and around calving, considerations in using dry cow therapy, and knowledge of the guideline. Several questions contained the option "other." Information from this option was taken into consideration but not analyzed. Using SurveyMonkey (www.surveymonkey.com), the questionnaire was sent by email by the first author (BKR) to the dairy farmers of the University Farm Animal Practice in Harmelen, the Netherlands, in May 2018. Two reminders were sent, with an interval of 2 wk. Based on the high response rate and interesting results, the research was then extended to reach dairy farmers linked with 11 other clinics (a final total of 1,942 farmers). All 12 clinics were members of Kernpraktijken Rundvee (Harmelen, the Netherlands), a collaborative linking farm animal veterinary clinics in the Netherlands. The dairy farms served by these clinics received an announcement from their own clinic before receiving the questionnaire, with an explanation of the goal of the research and the opportunity to opt out of the mailing list. One farmer opted out and was removed from the mailing list. The questionnaires were sent in November 2018, using the same software and with the same interval for sending reminders. To increase the response rate, we offered an estimate of completion time, emphasized the objective of the study, and provided a financial incentive for completion by offering entry in a drawing to win a gift certificate per participating clinic.

\section{Data Collection}

Additional information on farm characteristics and udder health was collected.

Farm Characteristics. Data on number of dairy cows per farm on reference date Dec. 28, 2018, were available for all farms from VeeOnline (www.veeonline .nl), an online national database of herd-specific data, managed by the Royal GD in Deventer, the Netherlands. Information about the type of farming (conventional or organic) and type of milking system used for farms of the University Farm Animal Practice was retrieved from the University Farm Animal Practice's management system. Any missing data concerning milking system and farm type for the farmers of the other clinics were retrieved through the vet clinics and added to the data set.

New High SCC. New high SCC during the dry period is a standard key performance indicator at herd level, calculated on all farms in the Netherlands participating in DHI, known as "new IMI." It is used as an evaluation tool to assess the SCC dynamics during the dry period. It is based on the percentage of cows with a low SCC before the dry period that develop a high SCC after the dry period. It is calculated as the proportion 
of animals with a high SCC after the dry period but a low SCC before the dry period, divided by all animals with a low SCC before dry-off. A change in SCC is considered a new high SCC when the SCC is $<250,000$ cells $/ \mathrm{mL}$ on the last DHI registration before dry-off and $>250,000$ cells $/ \mathrm{mL}$ on the first $\mathrm{DHI}$ registration after calving for multiparous cows. For heifers, the threshold is set at 150,000 cells $/ \mathrm{mL}$. A rolling average of new high SCC on herd level over the last 12 mo is provided at each test day. Data on new high SCC were collected from milk recording (DHI) at herd level, available for veterinarians in the Netherlands (www.pir-dap.nl). The yearly rolling average data on new high SCC were collected in the last 2 weeks of December 2018.

Defined Daily Dose. In the Netherlands, all antimicrobials are delivered through a veterinary clinic and, upon delivery, registered in a national database, Medirund (www.medirund.nl). Antimicrobials are divided into different categories per route of administration. The categories for mastitis and DCT are separate and include only intramammary tubes. Use is calculated as defined daily dose per animal year (DDDA/yr) at herd level (SDa, 2005). For DCT, each antimicrobial intramammary tube counts as one daily dose; thus, a cow that is dried off receives 4 DDDA for that year.

Knowledge of the Guideline. The current guideline for using DCT is based on the SCC at the last DHI before dry-off of each individual animal and has a different threshold for cows and heifers. Farmers were asked what this threshold was. Of the options given, 2 were wrong answers, 1 was correct, and the final option was "I don't know."

\section{Statistical Analysis}

The results of the questionnaire were merged in Microsoft Excel 2010 (Microsoft Corp., Redmond, WA). Statistical analysis was performed using $\mathrm{R}$ (version 3.5.2, R Foundation for Statistical Computing, Vienna, Austria). Supplemental Table S1 (https://doi.org/10 $.3168 /$ jds.2020-19133) shows the results and recoded categories. Descriptive results were used to check the data using Pearson's chi-squared test and Fisher's exact test. An association was considered significant if the $P$-value was $<0.05$. Univariable analysis was performed for all variables to investigate the association with new high SCC on herd level and relevance to be entered in a multivariable model. Clinic number was included as a fixed effect in all univariable and multivariable analysis to avoid confounding by differences between clinics. Multivariable analysis was performed using a generalized linear mixed model. The variables added to the model are indicated in Supplemental Table S1. Four variables were not included in the model; these were derived from follow-up questions (question 4) or had limited variation (questions 5, 15, and 22). Only complete cases were included in the final model. Model selection was performed using a backward elimination method based on the lowest Akaike information criterion (Akaike, 1974). From the final model profile likelihood confidence intervals for the effects were calculated. Results with a confidence interval not including zero were considered significant. Model checking was performed using deviance residuals. Residuals were checked for normality using a normal probability plot. Additionally, 2 models were made for the different groups of variables, to check the results separately. The variables related to farm characteristics and transition management were analyzed in a separate model, as well as the variables related to attitude toward the use of DCT.

\section{RESULTS}

\section{Descriptive Results}

A total of 690 questionnaires were answered online, resulting in a total response rate of $35.5 \%$. The mean herd size of respondents and DDDA/yr for DCT was higher than for nonrespondents, whereas the percentage of new high SCC and DDDA/yr for mastitis did not differ between the groups.

The number of farms per veterinary clinic ranged from 95 to 303 farms (Table 1). The response rate per clinic ranged from $24.8 \%$ to $45.9 \%$, and the mean herd size of the respondents per clinic from 89 to 144 dairy cows (Supplemental Table S2, https://doi.org/10 .3168/jds.2020-19133). Overall new high SCC per clinic ranged from $13.3 \%$ to $19.4 \%$. The number of farms per clinic is not mentioned, to ensure the privacy of the clinics.

\section{Farm Characteristics}

Herd Size and Milking System. The mean herd size of the respondents was 112 dairy cows. For analysis herd size was classified as $<80,80-120$, and $>120$ cows, resulting in 3 roughly equally sized groups of 227,219 , and 229 herds, respectively. A conventional milking parlor was most common, used in $73 \%$ of the farms; $24 \%$ used an automated milking system (AMS), and $3 \%$ had a different milking system (pipeline, other, or unknown). Henceforward, the milking systems other than AMS will be grouped together as "conventional."

Dry Cow Housing. Tiestall farms $(\mathrm{n}=4)$ were classified as "other" and were not further analyzed. The proportion of farms that housed the dry cows in cubicles was $84 \%$ (of which $71 \%$ of cubicles had mats 
or matrasses and 29\% had deep bedding; Supplemental Table S1, https://doi.org/10.3168/jds.2020-19133). The type of deep bedding used was not further specified. A minority (4\%) of farms housed the dry cows in a group pen with straw bedded pack, $9 \%$ had other housing, and $2 \%$ were unknown. The group with different housing was further analyzed and contained mainly farms with different housing systems throughout the dry period and combinations with pasture grazing in the summer months. Cubicles with deep bedding for the dry cows were more common on farms with $>120$ dairy cows $(P<0.01)$ than for smaller herds (Supplemental Table S3, https://doi.org/10.3168/jds.2020-19133). A group pen with straw bedded pack was more common in herds with $<80$ dairy cows than in larger herds $(P<$ 0.02). Farms with $>120$ cows were more likely to have a separate calving pen with straw bedding $(89 \%, P<$ 0.01 ), compared with $84 \%$ with a herd size of $<80-120$, and $67 \%$ of those $<80$.

\section{Transition Management}

The first 9 questions were related to the last (group of) cows dried off; $95 \%$ of respondents indicated that the methods described were common practice on their farms.

Reduction of Milk Yield. More than $70 \%$ of the respondents indicated that, before drying off cows, they took measures to reduce milk yield. Measures to reduce milk yield before dry-off were relatively more common on AMS (87\%) farms than on farms with conventional milking systems $(67 \%, P<0.01$; Supplemental Table S4, https://doi.org/10.3168/jds.2020-19133). The method most frequently applied among respondents with AMS was increasing the milking interval in combination with changing the ration (56\%). Among respondents with conventional milking systems, the percentage of farmers who changed the milking interval was $72 \%$, with or without changing the ration. We found no association between the method of milk yield reduction and herd size class.

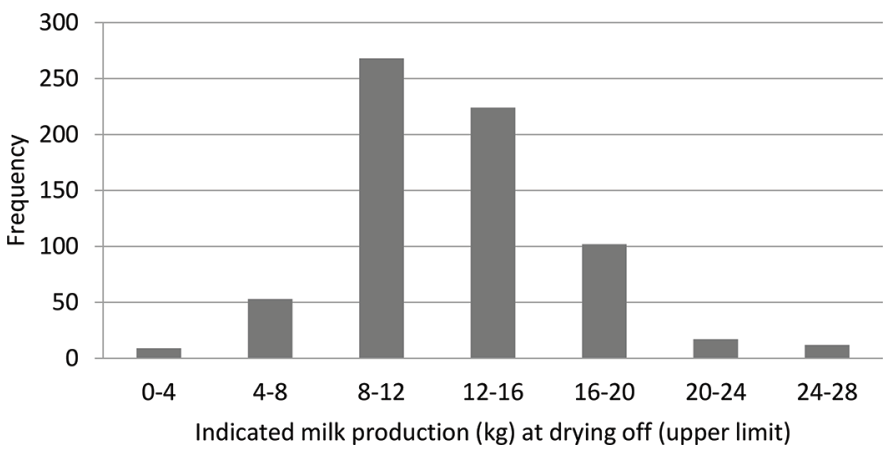

Figure 1. Milk production at drying off (upper limit) indicated by respondents for the last cow $(\mathrm{s})$ dried off $(\mathrm{n}=685)$.

Milk Yield at Dry-Off. In an open question, farmers were asked about the milk yield in the last $24 \mathrm{~h}$ for the cows that were dried off most recently. For further analysis their answers were transferred to an upper and lower limit. For example: "5 to $10 \mathrm{~kg}$ " was transferred to a lower limit of $5 \mathrm{~kg}$ and an upper limit of $10 \mathrm{~kg}$. The answer "less than $10 \mathrm{~kg}$ " was transferred to an upper limit of 10 and no lower limit. This resulted in a mean upper limit of $13.48 \mathrm{~kg}$ (SD 4.26) and a mean lower limit of $12.01 \mathrm{~kg}$ (SD 4.31; Figure 1).

Dip or Spray. Dipping or spraying the cows immediately after drying off, without repeating during the dry period, was most common (73\%). Dipping or spraying for a week or longer after drying off was indicated by $3.8 \%$ of the respondents, and $18 \%$ indicated they did not use dip or spray after drying off cows. Applying dip or spray after drying off was related to type of milking system and was more common on farms with conventional milking systems $(P<0.01)$.

Scraping Pens. The majority of respondents (53\%) scraped the cubicles of the dry cows to remove manure less often than the cubicles of lactating cows, whereas $45 \%$ scraped the cubicles of the dry cows as often as the lactating cows. Only $1 \%$ indicated that they scraped the cubicles for the dry cows more frequently than those for the lactating cows.

Table 1. Overview of annual variables of respondents versus nonrespondents of the questionnaire

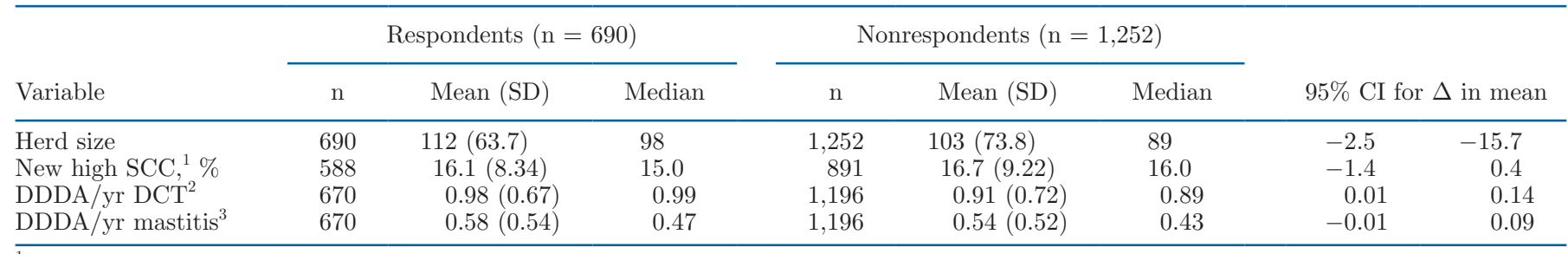

${ }^{1}$ New high SCC $(\%)=$ percentage of new high SCC on herd level during the dry period, based on an SCC threshold of 250,000 cells/mL for multiparous cows and 150,000 cells/mL for heifers.

${ }^{2} \mathrm{DDDA} / \mathrm{yr} \mathrm{DCT}=$ mean animal-defined daily dose for intramammary dry cow antimicrobials per herd.

${ }^{3} \mathrm{DDDA} / \mathrm{yr}$ mastitis = mean animal-defined daily dose for intramammary mastitis antimicrobials per herd. 
Milking Cow After Calving. We found that 38\% of respondents fully milk the cow within $2 \mathrm{~h}$ after calving. This was dependent on herd size class $(P<0.01)$ and milking system $(P<0.01)$. On farms with a herd size $>120$ or $80-120$, fully milking cows within $2 \mathrm{~h}$ after calving was more common (44 and $41 \%$, respectively) than on smaller farms. On farms with AMS this was $67 \%$, compared with $30 \%$ on farms with a conventional milking system.

Time in Calving Pen. We found no significant difference between herd size class or milking system related to how long before calving cows are moved to the calving pen. After calving, however, farms with more than 120 cows more often housed cows in a calving pen for several days before introducing them back in the herd $(41 \%, P<0.01)$. For herds with $80-120$ cows, the proportion was $29 \%$, and for $<80$, the proportion was $24 \%$.

\section{Attitude Toward the Use of Dry Cow Therapy}

Use of $\boldsymbol{D C T}$. In the questionnaire, we asked for the 2 most important criteria to successfully dry off cows without DCT. Reduction of milk yield was most often selected (69\%). Optimal hygiene during drying off $(41 \%)$ and a low infection rate on the farm $(27 \%)$ were also considered important criteria. The respondents that selected reduction of milk yield as an important criterion more often indicated that the last cows dried off had a milk yield $<12 \mathrm{~kg}$ at dry-off. Of the respondents, $24 \%$ indicated they never used DCT in cows with low SCC; $41 \%$ of respondents indicated that DCT was appropriate for cows with CM or a high SCC earlier in lactation; and $23 \%$ mentioned the factors "age," "milk leaking," or "high milk yield" as reasons to use DCT in low-SCC cows.

Knowledge of the Guideline. The majority of the respondents (53\%) answered incorrectly or indicated they did not know the thresholds of the guideline. We found no significant difference in knowledge of the guideline between farms with an AMS or conventional milking system or between different herd size classes.

\section{Statistical Analysis of New High SCC on Herd Level}

The mean proportion of new high SCC on herd level within the respondents' farms was $16.1 \%$ and was normally distributed (Figure 2). The final reduced model resulted in 541 complete cases. The variables significantly associated with a higher proportion of new high SCC on herd level during the dry period were dry cow housing other than cubicles and DDDA/yr for mastitis. In contrast, a lower proportion of new high SCC during
Proportion of new high scC on herd level

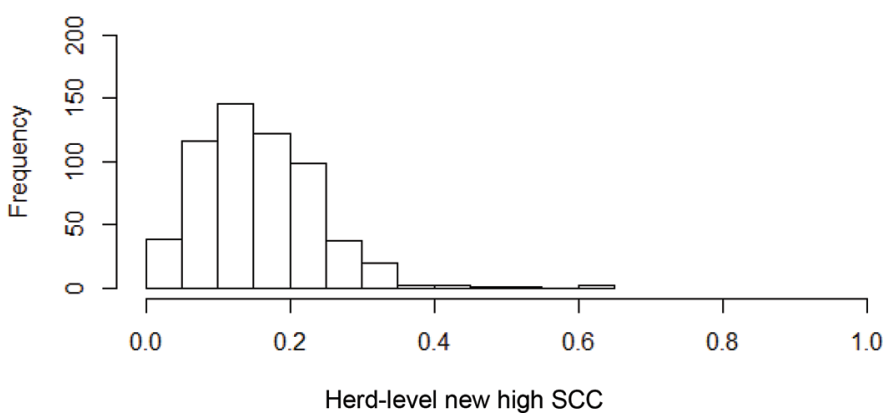

Figure 2. Distribution of the proportion of new high SCC during the dry period of 588 herds in 2018.

the dry period was associated with using dip or spray after drying off, the use DCT in low SCC cows, correct knowledge of the guideline, success factors for drying off without DCT, and DDDA/yr for DCT (Table 2). The 2 separate models on either farm characteristics and transition management or on the attitude toward the use of DCT showed very similar associations and significance compared with the final reduced combined model (Supplemental Tables S5 and S6, https://doi .org/10.3168/jds.2020-19133).

\section{DISCUSSION}

Our objectives were to describe the current management practices during the transition period that could influence udder health during the dry period and to investigate the associations of management on the proportion of new high SCC after the dry period. As expected, management practices varied considerably among the farmers we surveyed. There was consensus among respondents that reduction of milk yield before dry-off is a main criterion for successfully applying SDCT on their farm. The high percentage of farmers actually attempting to reduce milk yield before dry-off and the milk yield in the last $24 \mathrm{~h}$ before dry-off supports this. The proportion of new high SCC during the dry period in this study $(16.1 \%)$ was in line with the findings of Vanhoudt et al. (2018), who found a range of 16 to $18 \%$ new high SCC during the dry period on national level.

\section{Representativeness of Our Sample of Respondents}

The number of farms we approached for this questionnaire represents $12 \%$ of the total number of dairy farms in the Netherlands in 2018 (Royal GD, Deventer, 2018). The veterinary clinics were geographically spread in the 
Netherlands. The overall response rate was very high $(36 \%)$, and the lowest response rate per clinic was still $24 \%$. The level of DCT use was in line with the Dutch average (SDa, 2019). The herd size of the respondents was slightly higher than the Dutch average of 97 cows per farm in 2016 (Wageningen Livestock Research, 2018). Not only was the response rate high, but most questions were also answered by a high proportion of

Table 2. Parameter estimates from the final reduced linear regression model for new high SCC on herd level during the dry period of 541 complete cases

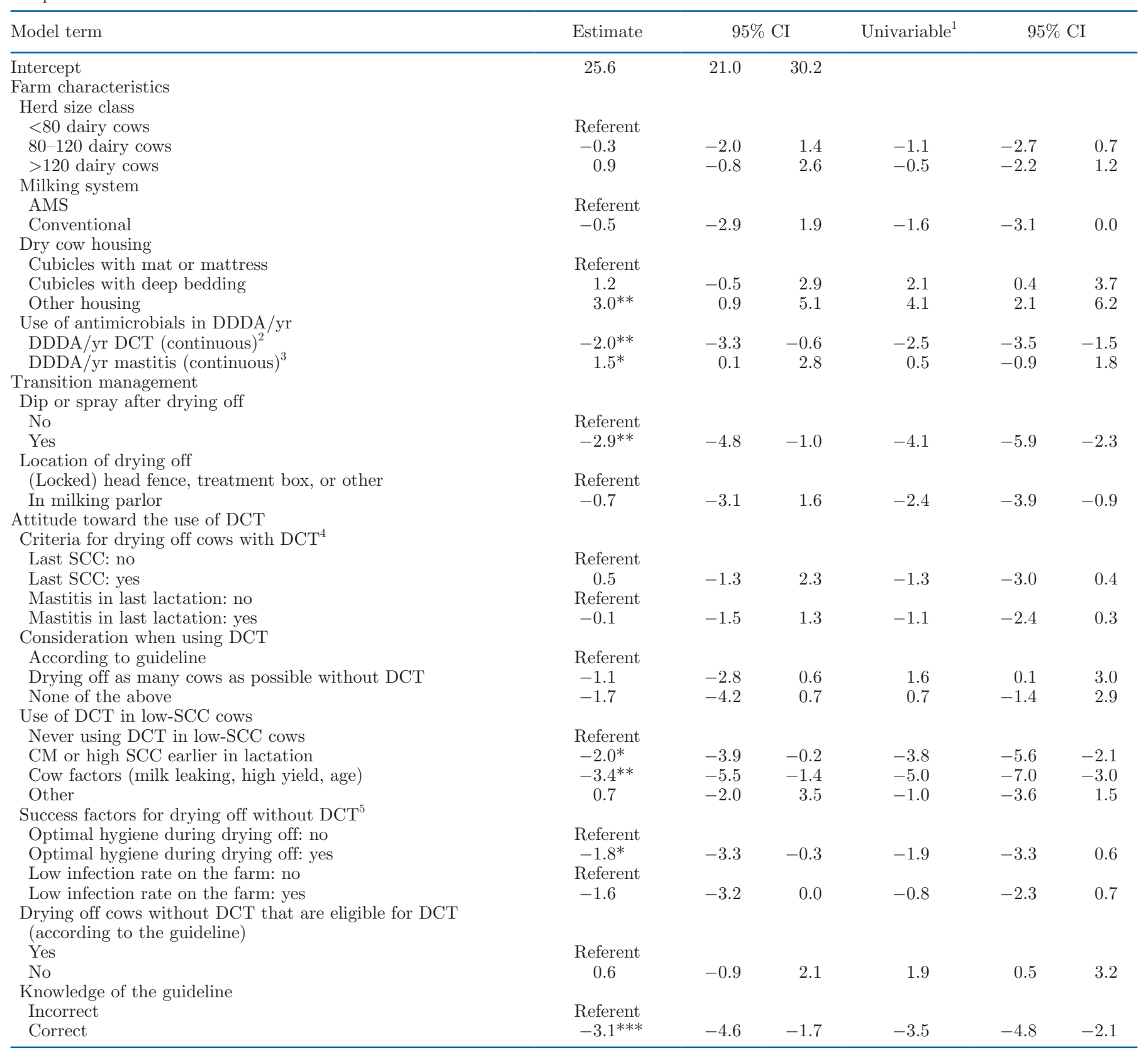

${ }^{1}$ Univariable estimates corrected for clinic number.

${ }^{2} \mathrm{DDDA} / \mathrm{yr}$ for DCT = mean animal-defined daily dose for intramammary dry cow antimicrobials per herd. This is a continuous variable.

${ }^{3} \mathrm{DDDA} / \mathrm{yr}$ for mastitis = mean animal-defined daily dose for intramammary mastitis antimicrobials per herd. This is a continuous variable.

${ }^{4}$ Criteria used by respondents for drying off cows with DCT (yes or no).

${ }^{5}$ Success factors considered important (yes or no) by respondents to successfully dry off cows without DCT.

*** $P<0.001 ; * * P<0.01 ; * P<0.05$. 
the respondents. The question with the lowest response rate $(86.5 \%)$ asked for a suggested SCC threshold for the use of SDCT. All other questions were answered by at least $96.5 \%$ of the respondents (Supplemental Table S1, https://doi.org/10.3168/jds.2020-19133). The percentage of farms with AMS (24\%) was exactly in line with the Dutch average (KOM, 2020), as was the percentage of organic farms (4\%; Skal, 2018). The results can therefore be considered to be representative for the Netherlands.

\section{Farm Characteristics}

In the univariable analysis of type of milking system, AMS was associated with a significantly higher proportion of new high SCC. Failure of milking hygiene and cleaning of the teats are challenges for AMS (Hovinen and Pyörälä, 2011). However, the association did not remain in the multivariable analysis. A confounding variable could have been the use of dip or spray after drying off, which was less common on farms with an AMS.

A high percentage of farms in our study housed the dry cows in cubicles with deep bedding. No data are available on what type of housing was used for dry cows in the past. We found that dry cow housing of the category "other" was strongly associated with a higher proportion of new high SCC. This category was regrouped for analyses and contained a variety of dry cow housing, including group pens with straw bedding, combinations of different housing systems throughout the dry period, and combinations with pasture grazing in the summer months. We can conclude that dry cow housing is relevant for new high SCC, but based on our data we cannot come to strong conclusions or recommendations.

We found that a higher use of DCT was negatively associated with new high SCC. However, the higher use in the model (Table 2) is an increase of the DDDA/yr for DCT by 1.0, whereas the mean DDDA/yr for DCT of the responders was 0.98 (SD 0.67). This means that only considerably higher use of DCT at farm level was associated with lower new high SCC. In contrast, the use of antimicrobials for mastitis was positively associated with new high SCC. Whereas the mean DDDA/ yr for mastitis of the respondents was 0.58 (SD 0.54), an increase in the DDDA/yr for mastitis by 1.0 was related to a $1.5 \%$ higher new high SCC. Also here we see that only a considerably higher use of antimicrobials for mastitis is related to an increase in new high SCC. The use of antimicrobials for mastitis could be related to the infection rate on the farm and therefore could influence the manifestation of CM in the next lactation (Green et al., 2002).

\section{Transition Management}

Dipping or spraying after drying off was associated with fewer new high SCC during the dry period. Teat dipping has long been advised (Neave et al., 1969) and is the most effective measure in the mastitis prevention plan on every dairy farm (Huijps et al., 2010). The importance of teat dipping after the last milking has long been recognized, whether DCT is used or not (Funk et al., 1982; Whist et al., 2006). We did not ask the reasons for not applying dip or spray, but it was less frequently done on farms with AMS. This could be because, on these farms, cows were dried off at a head lock fence or in the robot, where dip or spray is not as readily available as in a milking parlor. With $18 \%$ of the respondents not using dip or spray after drying off cows, there are opportunities for veterinarians to discuss this with farmers, as it is clearly not routine on all farms.

Optimal hygiene during the dry period was considered less important than reduction of milk yield, optimal hygiene during drying off, and a low infection rate. The most common management practice around cleaning the dry cow pens was to scrape them less often than the pens of the lactating cows. Pens have been described as being scraped more often on farms with more udder health problems (Green et al., 2008). We can conclude that during the dry period other factors are considered more important than hygiene, even though we cannot compare our findings with management before the introduction of SDCT.

Farms with more than 120 cows more often fully milked their cows after calving within $2 \mathrm{~h}$ than did smaller farms. This early milking could be due to larger herds working according to protocol or having more personnel or equipment such as a mobile milking machine available. Indeed, milking cows within $2 \mathrm{~h}$ of calving was seen more often on farms with AMS than on those with a conventional system, most probably because an AMS is readily available $24 \mathrm{~h}$ a day. Further, as Green et al. (2007) found, cows milked within several hours of calving tend to have a lower SCC in early lactation and lower CM after calving. Flushing out bacteria present in the teat canal could be protective, but this could not be confirmed in our study for the proportion of new high SCC during the dry period.

In this research, the large majority of farms with an AMS reduced milk yield before dry-off, mostly by changing the milking frequency in combination with changing the ration. In an AMS this can be achieved relatively easily by changing the milking intervals. In farms with conventional milking systems, however, milk yield was also often reduced before dry-off. The most common method used was lowering the milking 
frequency, which requires more organization with a conventional milking system. This seems to be an effort that farmers are willing to make, and, as Tucker et al. (2009) found, lowering the milking frequency is a successful method for reducing milk yield before dry-off. The mean upper limit of only $13.5 \mathrm{~kg}$ of milk in the last $24 \mathrm{~h}$ of drying off suggests that the strategy is successful. Similar results have been found in Finland, where Vilar et al. (2018) found that $86 \%$ of farms reduced yield to $15 \mathrm{~kg} / \mathrm{d}$ or less at dry-off, with $87 \%$ of farms doing this by changing the ration and restricting feed intake. This does contrast with a study of dairy farmers in northern Germany (Bertulat et al., 2015), in which the number of farmers that lowered milk yield before dry-off was only $27 \%$ ( $12 \%$ by lowering the milking frequency and $15 \%$ by changing the ration). On these German farms, however, almost $80 \%$ still used BDCT, and only $3 \%$ of farms used AMS.

Reduction of milk yield before drying off was considered an important success factor for drying off without DCT. It was one of the recommendations in the guideline launched by the Royal Dutch Veterinary Association $(\mathrm{KNMvD}, 2013)$ and became a frequently advised management tool. Based on the results of this research, this advice seems to have been adopted by many farmers. Other research investigating the relationship of milk yield at dry-off and risk of new high SCC found an association (Dingwell et al., 2004; Rajala-Schultz et al., 2005; Henderson et al., 2016). This is confirmed by Gott et al. (2016), who found that the effect differed per parity, with gradual cessation being related to increased odds of IMI at calving for multiparous cows. Although reduction of milk yield was considered important and applied by many respondents, we found no association with new high SCC on herd level. This could be due to the lack of variation in milk yield before dry-off, or high-yielding cows could be dried off using DCT, because high milk yield was one of the cow factors that was often mentioned as reason for using DCT in low-SCC cows.

\section{Attitude Toward the Use of Dry Cow Therapy}

Last SCC before drying off was the main criterion for drying off with DCT, which is in line with what the guideline prescribes. We found that correct knowledge of the guideline was associated with a lower new high SCC during the dry period. This suggests that applying the guideline correctly has a positive effect on udder health. More than 5 years after its introduction, the threshold of the guideline was known by only half of the farmers. This can be considered low, especially because during the questionnaire they could have looked up the correct answer. Respondents had lower rates of new high SCC during the dry period if they used DCT in low-SCC cows with specific risk factors (milk leaking, high yield, age, good milk letdown) and in those that had CM or a high SCC earlier in lactation. They therefore seemed successful in preventing new high SCC during the dry period by selecting the cows at risk.

The 2 success factors for drying off without DCT (a low infection rate on the farm and hygiene during drying off), based on the farmers' point of view, were related to a lower new high SCC. Similarly, hygiene measures associated with the administration of DCT were associated with lower SCC in early lactation, as in the study of Green et al. (2008).

\section{Limitations}

As with any questionnaire, the answers might not fully reflect true practices on the farm. However, by specifically asking about the last cows dried off in the first part of the questionnaire, the authors attempted to avoid answers with a social desirability bias. Further, the variable new high SCC during the dry period concerns the percentage of cows with low SCC before the dry period that have become high SCC cows after calving. We are aware that this does not give an indication of the proportion of cows with a high SCC before the dry period; nor did we have information on $\mathrm{CM}$ rate in the herds. We are also aware that the variable new high SCC may be affected because the test day for DHI can be several weeks before the start or end of the dry period, leaving time during lactation in which a new high SCC could occur. However, by collecting information from a large number of farms, we have compensated for variation in infection rate per farm. Finally, although internal teat sealants are known to be protective against new high SCC (Rabiee and Lean, 2013; Krömker et al., 2014; Vanhoudt et al., 2018), this research did not include the use of internal teat sealants, because the effect can only be evaluated on individual cow level, and we only had access to new high SCC during the dry period on herd level.

Differences in new high SCC and DDDA/yr per clinic could be due to milk production level or differences in ration per geographical region. In the model, this was addressed by correcting farm-related data for clinic, herd size, and milking system. Finally, as Scherpenzeel et al. (2018) have shown, attitudes of veterinarians toward antimicrobial use and SDCT in the Netherlands vary. Although its effect on farm-level management of risk factors cannot be entirely excluded, the high response rate per clinic and including clinic as a variable in the model should have limited this. 


\section{CONCLUSIONS}

Udder health does not seem affected by reduction in use of DCT, and the introduction of SDCT in the Netherlands has therefore been successful. This research provides useful information on the variation in management practices that Dutch farmers apply around dry-off in light of SDCT. Most farmers indicate that reduction of milk yield and optimal hygiene at dryoff are important success factors. Data analysis shows that using dip or spray after the last milking should be recommended, whereas low-SCC cows with previous udder health issues might receive DCT in contrast to the current guideline. The housing of dry cows seems influential but needs further study.

\section{ACKNOWLEDGMENTS}

The authors thank the farmers that participated in the questionnaire and the clinics that are a member of Kernpraktijken Rundvee (Harmelen, the Netherlands) for their cooperation in this research. The authors have not stated any conflicts of interest.

\section{REFERENCES}

Akaike, H. 1974. A new look at the statistical model identification. IEEE Trans. Automat. Contr. 19:716-723. https://doi.org/10 $.1109 /$ TAC.1974.1100705.

Bertulat, S., C. Fischer-Tenhagen, and W. Heuwieser. 2015. A survey of drying-off practices on commercial dairy farms in northern Germany and a comparison to science-based recommendations. Vet. Rec. Open 2:e00068. https://doi.org/10.1136/vetreco-2014 -000068 .

Bradley, A. J., S. De Vliegher, M. J. Green, P. Larrosa, B. Payne, E. S. Van de Leemput, O. Samson, D. Valckenier, T. Van Werven, H. W. F. Waldeck, V. White, and L. Goby. 2015. An investigation of the dynamics of intramammary infections acquired during the dry period on European dairy farms. J. Dairy Sci. 98:6029-6047. https: //doi.org/10.3168/jds.2014-8749.

Bradley, A. J., and M. J. Green. 2004. The importance of the nonlactating period in the epidemiology of intramammary infection and strategies for prevention. Vet. Clin. North Am. Food Anim. Pract. 20:547-568. https://doi.org/10.1016/j.cvfa.2004.06.010.

Cameron, M., S. L. McKenna, K. A. MacDonald, I. R. Dohoo, J. P. Roy, and G. P. Keefe. 2014. Evaluation of selective dry cow treatment following on-farm culture: Risk of postcalving intramammary infection and clinical mastitis in the subsequent lactation. J. Dairy Sci. 97:270-284. https://doi.org/10.3168/jds.2013-7060.

Dingwell, R. T., D. F. Kelton, and K. E. Leslie. 2003. Management of the dry cow in control of peripartum disease and mastitis. Vet. Clin. North Am. Food Anim. Pract. 19:235-265. https://doi.org/ 10.1016/S0749-0720(02)00072-5.

Dingwell, R. T., K. E. Leslie, Y. H. Schukken, J. M. Sargeant, L. L. Timms, T. F. Duffield, G. P. Keefe, D. F. Kelton, K. D. Lissemore, and J. Conklin. 2004. Association of cow and quarter-level factors at drying-off with new intramammary infections during the dry period. Prev. Vet. Med. 63:75-89. https://doi.org/10.1016/j .prevetmed.2004.01.012.

Eberhart, R. J. 1986. Management of dry cows to reduce mastitis. J. Dairy Sci. 69:1721-1732. https://doi.org/10.3168/jds.S0022 $-0302(86) 80591-4$.
Funk, D. A., A. E. Freeman, and P. J. Berger. 1982. Environmental and physiological factors affecting mastitis at drying off and postcalving. J. Dairy Sci. 65:1258-1268. https://doi.org/10.3168/jds .S0022-0302(82)82339-4.

Gott, P. N., P. J. Rajala-Schultz, G. M. Schuenemann, K. L. Proudfoot, and J. S. Hogan. 2016. Intramammary infections and milk leakage following gradual or abrupt cessation of milking. J. Dairy Sci. 99:4005-4017. https://doi.org/10.3168/jds.2015-10348.

Green, M. J., A. J. Bradley, G. F. Medley, and W. J. Browne. 2007. Cow, farm, and management factors during the dry period that determine the rate of clinical mastitis after calving. J. Dairy Sci. 90:3764-3776. https://doi.org/10.3168/jds.2007-0107.

Green, M. J., A. J. Bradley, G. F. Medley, and W. J. Browne. 2008. Cow, farm, and herd management factors in the dry period associated with raised somatic cell counts in early lactation. J. Dairy Sci. 91:1403-1415. https://doi.org/10.3168/jds.2007-0621.

Green, M. J., L. E. Green, G. F. Medley, Y. H. Schukken, and A. J. Bradley. 2002. Influence of dry period bacterial intramammary infection on clinical mastitis in dairy cows. J. Dairy Sci. 85:25892599. https://doi.org/10.3168/jds.S0022-0302(02)74343-9.

Halasa, T., O. Østerås, H. Hogeveen, T. van Werven, and M. Nielen. 2009. Meta-analysis of dry cow management for dairy cattle. Part 1. Protection against new intramammary infections. J. Dairy Sci. 92:3134-3149. https://doi.org/10.3168/jds.2008-1740.

Henderson, A. C., C. D. Hudson, A. J. Bradley, V. E. Sherwin, and M. J. Green. 2016. Prediction of intramammary infection status across the dry period from lifetime cow records. J. Dairy Sci 99:5586-5595. https://doi.org/10.3168/jds.2015-10684.

Hovinen, M., and S. Pyörälä. 2011. Invited review: Udder health of dairy cows in automatic milking. J. Dairy Sci. 94:547-562. https:/ /doi.org/10.3168/jds.2010-3556.

Huijps, K., H. Hogeveen, T. J. G. M. Lam, and A. G. J. M. Oude Lansink. 2010. Costs and efficacy of management measures to improve udder health on Dutch dairy farms. J. Dairy Sci. 93:115-124. https://doi.org/10.3168/jds.2009-2412.

KNMvD. 2013. Richtlijn Antimicrobiële Middelen Bij Het Droogzetten van Melkkoeien. Accessed Jun. 1, 2020. https://www .kwaliteitdiergeneeskunde.nl.

KOM. 2020. Overzicht Soorten/Typen Melkstallen (Aantal Bedrijven). Accessed Jun. 1, 2020. http://www.stichtingkom.nl/index .php/stichting_kom/category/statistiek.

Krömker, V., N. T. Grabowski, and J. Friedrich. 2014. New infection rate of bovine mammary glands after application of an internal teat seal at dry-off. J. Dairy Res. 81:54-58. https://doi.org/10 $.1017 /$ S0022029913000599.

Lam, T. J. G. M., J. Jansen, and R. J. Wessels. 2017. The RESET Mindset Model applied on decreasing antibiotic usage in dairy cattle in the Netherlands. Ir. Vet. J. 70:5. https://doi.org/10.1186/ s13620-017-0085-x.

Madouasse, A., W. J. Browne, J. N. Huxley, F. Toni, A. J. Bradley, and M. J. Green. 2012. Risk factors for a high somatic cell count at the first milk recording in a large sample of UK dairy herds. J. Dairy Sci. 95:1873-1884. https://doi.org/10.3168/jds.2011-4801.

Neave, F. K., F. H. Dodd, R. G. Kingwill, and D. R. Westgarth. 1969. Control of mastitis in the dairy herd by hygiene and management. J. Dairy Sci. 52:696-707. https://doi.org/10.3168/jds.S0022 $-0302(69) 86632-4$

OIE. 2016. The OIE Strategy on Antimicrobial Resistance and the Prudent Use of Antimicrobials. Accessed Dec. 1, 2019. https: //www.oie.int/fileadmin/Home/eng/Media_Center/docs/pdf/ PortailAMR/EN_OIE-AMRstrategy.pdf.

Østerås, O., and L. Sølverød. 2009. Norwegian mastitis control programme. Ir. Vet. J. 62(S4):S26-S33. https://doi.org/10.1186/2046 -0481-62-S4-S26.

Rabiee, A. R., and I. J. Lean. 2013. The effect of internal teat sealant products (Teatseal and Orbeseal) on intramammary infection, clinical mastitis, and somatic cell counts in lactating dairy cows: A meta-analysis. J. Dairy Sci. 96:6915-6931. https://doi.org/10 $.3168 /$ jds.2013-6544.

Rajala-Schultz, P. J., J. S. Hogan, and K. L. Smith. 2005. Short communication: Association between milk yield at dry-off and 
probability of intramammary infections at calving. J. Dairy Sci. 88:577-579. https://doi.org/10.3168/jds.S0022-0302(05)72720-X.

Royal G. D., Deventer. 2018. Monitoring GD Diergezondheid. Accessed Jun. 1, 2020. https://www.gddiergezondheid.nl/ /media/ Files/Monitoringsflyers/Rund/Hoofdpunten monitoring rund 2018-4.ashx.

Sampimon, O., H. W. Barkema, I. Berends, J. Sol, and T. Lam. 2009. Prevalence of intramammary infection in Dutch dairy herds. J. Dairy Res. 76:129-136. https://doi.org/10.1017/ S0022029908003762.

Santman-Berends, I. M. G. A., J. M. Swinkels, T. J. G. M. Lam, J. Keurentjes, and G. van Schaik. 2016. Evaluation of udder health parameters and risk factors for clinical mastitis in Dutch dairy herds in the context of a restricted antimicrobial usage policy. J. Dairy Sci. 99:2930-2939. https://doi.org/10.3168/jds.2015-10398.

Scherpenzeel, C. G. M., I. E. M. Den Uijl, G. van Schaik, R. G. M. Olde Riekerink, J. M. Keurentjes, and T. J. G. M. Lam. 2014. Evaluation of the use of dry cow antibiotics in low somatic cell count cows. J. Dairy Sci. 97:3606-3614. https://doi.org/10.3168/ jds.2013-7655.

Scherpenzeel, C. G. M., I. M. G. A. Santman-Berends, and T. J. G. M. Lam. 2018. Veterinarians' attitudes toward antimicrobial use and selective dry cow treatment in the Netherlands. J. Dairy Sci. 101:6336-6345. https://doi.org/10.3168/jds.2017-13591.

Scherpenzeel, C. G. M., S. H. W. Tijs, I. E. M. den Uijl, I. M. G. A. Santman-Berends, A. G. J. Velthuis, and T. J. G. M. Lam. 2016. Farmers' attitude toward the introduction of selective dry cow therapy. J. Dairy Sci. 99:8259-8266. https://doi.org/10.3168/ jds.2016-11349.

SDa. 2005. Standard Operating Procedure. Accessed Jun. 1, 2020. https://cdn.i-pulse.nl/autoriteitdiergeneesmiddelen/userfiles/ Publicaties/sda-standard-operating-procedure-dg-standaard -januari-2015.pdf.

SDa. 2019. Usage of Antibiotics in Agricultural Livestock in the Netherlands in 2018. Accessed Jan. 6, 2020. http://www .autoriteitdiergeneesmiddelen. $\mathrm{nl} / \mathrm{nl} /$ publicaties/sda-rapporten -antibioticumgebruik.
Skal. 2018. Jaarverslag 2018. Accessed Jan. 6, 2020. http://www.skal $. n l /$ assets/Publicaties/Skal-jaarverslag-def.pdf.

Tucker, C. B., S. J. Lacy-Hulbert, and J. R. Webster. 2009. Effect of milking frequency and feeding level before and after dry off on dairy cattle behavior and udder characteristics. J. Dairy Sci. 92:3194-3203. https://doi.org/10.3168/jds.2008-1930.

Vanhoudt, A., K. van Hees-Huijps, A. T. M. van Knegsel, O. C. Sampimon, J. C. M. Vernooij, M. Nielen, and T. van Werven. 2018 Effects of reduced intramammary antimicrobial use during the dry period on udder health in Dutch dairy herds. J. Dairy Sci. 101:3248-3260. https://doi.org/10.3168/jds.2017-13555.

Vilar, M. J., M. Hovinen, H. Simojoki, and P. J. Rajala-Schultz. 2018. Short communication: Drying-off practices and use of dry cow therapy in Finnish dairy herds. J. Dairy Sci. 101:7487-7493. https: //doi.org/10.3168/jds.2018-14742.

Wageningen Livestock Research. 2018. Feiten En Cijfers over de Nederlandse Veehouderijsectoren 2018. Accessed Jan. 6, 2020. https:/ /edepot.wur.nl/464128.

Whist, A. C., O. Østerås, and L. Sølverød. 2006. Clinical mastitis in Norwegian herds after a combined selective dry-cow therapy and teat-dipping trial. J. Dairy Sci. 89:4649-4659. https://doi.org/10 .3168/jds.S0022-0302(06)72515-2.

WHO. 2015. Global Action Plan on Antimicrobial Resistance. Accessed May 24, 2019. http://www.who.int/antimicrobial-resistance/ publications/global-action-plan/en.

WUR. 2008. Convenant antibioticaresistentie dierhouderij, 08-12-2008. Accessed Jan. 6, 2020. https://edepot.wur.nl/118614.

\section{ORCIDS}

B. Krattley-Roodenburg (๑) https://orcid.org/0000-0002-4421-3919

L. J. Huybens ํㅜ https://orcid.org/0000-0003-1718-9236

M. Nielen ๑ https://orcid.org/0000-0001-6909-877X

T. van Werven ๑ https://orcid.org/0000-0003-2391-0253 